not to have an effect at the $0 \cdot 2$ significance level. For this reason, we again conclude that we could find no clear relation between the age at onset of diabetes and the residual insulin secretory capacity of $\beta$ cells.

Table Age relation of $C$ peptide excretion by diabetic children with years after onset of disease. Figures in parentheses are percentages

\begin{tabular}{|c|c|c|c|c|c|c|c|}
\hline \multirow{2}{*}{$\begin{array}{l}\text { Age at } \\
\text { diagnosis } \\
\text { (years) }\end{array}$} & \multicolumn{7}{|c|}{ Years after diagnosis } \\
\hline & $0-0 \cdot 1$ & $0 \cdot 1-1$ & $1-2$ & $2-3$ & $3-4$ & $4-5$ & $5-6$ \\
\hline $0-5$ & $\begin{array}{l}10 / 11 \\
(91)\end{array}$ & - & $\begin{array}{l}1 / 6 \\
(17)\end{array}$ & $\begin{array}{l}2 / 9 \\
(22)\end{array}$ & $\begin{array}{l}0 / 6 \\
(0)\end{array}$ & $\begin{array}{l}0 / 8 \\
(0)\end{array}$ & $\begin{array}{l}(1 / 8 \\
(0)\end{array}$ \\
\hline $5-10$ & $\begin{array}{l}10 / 16 \\
(63)\end{array}$ & $\begin{array}{l}6 / 11 \\
(55)\end{array}$ & $\begin{array}{l}9 / 23 \\
(39)\end{array}$ & $\begin{array}{l}4 / 19 \\
(21)\end{array}$ & $\begin{array}{l}1 / 25 \\
(4)\end{array}$ & $\begin{array}{l}1 / 25 \\
(4)\end{array}$ & $\begin{array}{l}3 / 19 \\
(16)\end{array}$ \\
\hline $10-15$ & $\begin{array}{l}18 / 23 \\
(78)\end{array}$ & $\begin{array}{l}9 / 18 \\
(50)\end{array}$ & $\begin{array}{l}10 / 21 \\
(48)\end{array}$ & $\begin{array}{l}2 / 13 \\
(15)\end{array}$ & $\begin{array}{l}1 / 12 \\
(8)\end{array}$ & $\begin{array}{l}3 / 14 \\
(21)\end{array}$ & $\begin{array}{l}2 / 8 \\
(25)\end{array}$ \\
\hline
\end{tabular}

\section{Steroid responsive nephrotic syndrome in Asians}

Sir,

We have read with interest the recent reports by Sharples et $a l^{\prime}$ and Feehally et $a l^{2}$ on the high incidence of steroid responsive nephrotic syndrome in Asians living in England.

The question, however, remained open as to whether it is due to environmental or genetic factors. To provide additional information to this matter we would like to ? present our experience with steroid responsive nephrotic syndrome among Hungarian gypsies who migrated to central Europe from the Indian subcontinent and share some common genetic features with the Asians in question.

The referral area of our hospital (Baranya County) has a population of 440000 and gypsies amount to $5 \%$ of the general population. The number of children aged 3-14 years is 73200 , including 7200 gypsies. During the 10 year period of 1975-84, 28 cases with steroid responsive nephrotic syndrome were admitted, 18 of the 28 being gypsy. The annual incidence of steroid responsive nephrotic syndrome among gypsies is therefore 2.5 per $10^{4}$, while among non-gypsies it is 0.15 per $10^{4}\left(\mathrm{p}<0.001 ; \chi^{2}\right.$ test $)$.

Since Hungarian gypsies are living under very different social, cultural, and economical conditions from those of Asians in England, our data strongly suggest that genetic factors play the major role in the higher incidence of $\infty$ steroid responsive nephrotic syndrome among Asians.

\section{References}

' Sharples PM, Poulton J, White RHR. Steroid responsive nephrotic syndrome is more common in Asians. Arch Dis Child 1985;60:1014-7.

2 Feehally J, Kendell NP. Swift PGF, Walls J. High incidence of minimal change nephrotic syndrome in Asians. Arch Dis Child 1985:60:1018-20.

M Horvath and E Sulyok County Children's Hospital, H-7624 Pécs, Hungary 